\section{А.И. Савин}

\section{Героизм, герои и награды: «героическая сторона» Великой Отечественной войны в воспоминаниях современников}

doi:10.31518/2618-9100-2021-3-13

УДК 93/94

Выходные данные для цитирования:

Савин А.И. Героизм, герои и награды: «героическая сторона» Великой Отечественной войны в воспоминаниях современников // Исторический курьер. 2021.№ 3 (17). С. 117-126. URL: http:// istkurier.ru/data/2021/ISTKURIER-2021-3-13.pdf
A.I. Savin ${ }^{*}$

\section{Heroism, Heroes and Awards: "Heroic Side" of the Great Patriotic War in the Memoirs of Contemporaries}

doi:10.31518/2618-9100-2021-3-13

How to cite:

Savin A.I. Heroism, Heroes and Awards: "Heroic Side" of the Great Patriotic War in the Memoirs of Contemporaries // Historical Courier, 2021, No. 3 (17), pp. 117-126. [Available online:] http:// istkurier.ru/data/2021/ISTKURIER-2021-3-13.pdf

Abstract. The article analyzes the phenomenon of military heroism basing on interviews with frontline tankmen as representatives of one of the most heroic military specialties. As a result, the author comes to the conclusion about the high efficiency of the heroic concept and state policy aimed at glorifying the Soviet society, first of all, the soldiers and commanders of the Red Army. Military orders and medals were a powerful moral incentive to perform complex combat missions, played an important role in the adaptation of young recruits to military conditions as they all gained confidence in their strengths, promoted the recognition of young people as combat comrades, and raised the authority of those awarded as commanders. The transformation of the order bearers into an elite group dictated the most careful attitude towards them on the part of the unit command, which increased their chances of surviving until Victory, at the same time making it possible to share their combat experience. While giving such a high assessment to the heroic concept, it is worth mentioning that the mechanisms of the functioning of the award system did not always adequately reward the sacrificial heroism of the Soviet people, especially average soldiers, female military personnel and junior command personnel who were far from the high command and related privileges.

Keywords: Great Patriotic War; heroes; heroism; orders; incentive; memories; veterans; tankmen.

The article has been received by the editor on 12.05.2021.

Full text of the article in Russian and references in English are available below.

Аннотация. В настоящей статье предпринят анализ феномена военного героизма с основой на интервью фронтовиков-танкистов как представителей одной из наиболее героических воинских специальностей. В результате автор приходит к выводу о высокой эффективности героического концепта и государственной политики, направленной на героизацию советского социума, в первую очередь - солдат и командиров Красной армии. Боевые ордена и медали являлись мощным моральным стимулом к выполнению сложных боевых задач, играли колоссальную роль в адаптации молодого пополнения к военным условиям, вселяли уверенность в своих силах, способствовали признанию молодежи боевыми товарищами, высоко поднимали авторитет награжденных как командиров. Превращение орденоносцев в элитарную группу диктовало максимально бережное отношение к ним со стороны командования частей, что увеличивало их шансы дожить до Победы, одновременно давая возможность делиться боевым опытом. Давая такую высокую оценку героическому концепту, не следует забывать, что механизмы функционирования наградной системы

\footnotetext{
* Савин Андрей Иванович, кандидат исторических наук, Институт истории Сибирского отделения Российской академии наук, Новосибирск, Россия, e-mail: a_savin_2004@mail.ru

Savin Andrey Ivanovich, Candidate of Historical Sciences, Institute of History of the Siberian Branch of the Russian Academy of Sciences, Novosibirsk, Russia, e-mail: a_savin_2004@mail.ru
} 
не всегда адекватно вознаграждали жертвенный героизм советских людей, особенно рядовых бойцов, женщин-военнослужащих и младшего командного состава, далеких от высшего командования и связанных с ним привилегий.

Ключевые слова: Великая Отечественная война; герои; героизм; ордена; стимул; воспоминания; ветераны; танкисты.

Введение. Процесс героизации довоенной советской действительности, стремительно набиравший обороты с начала 1930-х гг., достиг к 1941 г. своего апогея. Новый советский человек являлся, как гласила советская пропаганда, человеком героическим, а Советский Союз превратился в настоящую страну героев, хозяев своей судьбы, которым по плечу любые подвиги и свершения. В течение предвоенного десятилетия сформировалась целая плеяда официально признанных героев, а также была создана эффективная наградная система. Значительный вклад в героизацию повседневности внесло участие СССР в больших и малых военных конфликтах второй половины 1930-х гг., начиная с гражданской войны в Испании и заканчивая Финской войной. В основных своих чертах этот героический концепт сохранился в годы Великой Отечественной войны, тем не менее претерпев определенные трансформации.

По-видимому, можно говорить о трех главных специфических чертах советского героизма времен Великой Отечественной войны. Во-первых, речь идет о феномене массового героизма. Что касается институциональных героев, создание которых осуществлялось в результате официального акта государства - награждения орденом или медалью СССР, то за 1941-1945 гг. орденами и медалями СССР были награждены около 13,2 млн чел. Эта цифра приводится без учета награждений медалями за оборону, взятие и освобождение городов и территорий, вручавшихся от имени Президиума Верховного Совета СССР, которыми также были награждены сотни тысяч человек. Речь идет о беспрецедентном числе награжденных, которое никогда не было больше достигнуто в советской истории, даже в брежневский период. Массовость награждений, особенно на завершающем этапе войны, привела к тому, что фактически высший орган партийно-государственной власти в СССР - Политбюро ЦК ВКП(б) во главе с И.В. Сталиным - фактически превратился в 1944-1945 гг. в «наградную инстанцию». Материалы этого периода свидетельствуют о том, что главным содержанием деятельности Политбюро стало утверждение наградных представлений советских элит, неудержимым потоком хлынувших на верхний этаж властной пирамиды. Из заседания в заседание Сталин занимался практически только наградными вопросами, и это при том, что основной вал наградных документов шел через армейские структуры и Президиум Верховного Совета СССР.

Во-вторых, военный героизм был неотделим от русских национальных и патриотических ценностей, окончательно реабилитированных во второй половине 1941 г. В своей речи на параде 7 ноября 1941 г. Сталин призвал армию и народ вдохновляться в сражениях «мужественными образами наших великих предков - Александра Невского, Дмитрия Донского, Кузьмы Минина и Дмитрия Пожарского, Суворова и Кутузова». На службу патриотической пропаганде были мобилизованы все формы литературы и искусства. Сталинский идеологический поворот был однозначно понят обществом как попытка «поднять патриотизм масс историческими примерами героики русского народа», такими как «подвиги времен Александра Невского, Суворова, 1812 г. и т.п.». Показательно, что реабилитация русского героизма практически не затронула Первую мировую войну, хотя соответствующие предложения поступали на адрес Сталина. Так, ветеран Первой мировой войны из Новосибирска В.Е. Маркевич писал Сталину в мае 1942 г. о том, что «целесообразнее было бы использовать в первую очередь живых героев, проливавших кровь за русскую землю и русский народ, [...] колотивших немцев и в Пруссии, и в Австрии, получивших за это боевые награды, раны, увечья...». Именно «живые участники войн - герои, ветераны, инвалиды, считал Маркевич, - окажутся незаменимыми агитаторами и будут поднимать героику совет- 
ских народов, культивировать дух самопожертвования, храбрости, отваги и непобедимости» ${ }^{.}$В июле 1942 г. была отклонена инициатива Управления пропаганды и агитации ЦК ВКП(б) широко отметить в печати 1 августа 1942 г. 28-ю годовщину Первой мировой войны ${ }^{2}$.

В-третьих, в годы войны сложился героический дискурс, который вплоть до сегодняшнего дня доминирует в политике памяти. Глоризация побед началась уже в начале 1942 г., после первого катастрофического этапа войны. Победа под Москвой и радужные надежды на успешную летнюю кампанию 1942 г. привели к первым шагам в ходе войны, направленным на расширение советской наградной системы. 19 мая 1942 г., уже в ходе Харьковской катастрофы, Политбюро ЦК ВКП(б) приняло постановление об учреждении ордена Отечественной войны двух степеней, введении гвардейских званий и утверждении нагрудных знаков «Снайпер», «Отличный пулеметчик», «Отличный минометчик», «Отличный артиллерист», «Отличный танкист» ${ }^{3}$. Позднее, как известно, будет учрежден еще целый ряд орденов и медалей ${ }^{4}$. При этом население также вносило свою лепту в расширение наградной системы, выступая с идеями новых орденов и медалей. Например, 5 января 1943 г. художник Н.Г. Рудин обратился с письмом на имя Г.М. Маленкова, в котором предлагал учредить орден «За патриотический подвиг» для награждения лиц из числа колхозников и интеллигенции, пожертвовавших свои сбережения на строительство самолетов и танков для Красной армии, а также активно участвовавших в сборе продовольствия для усиления питания рабочих промышленности. Кроме этого, Рудин предлагал учредить орден «Красного партизана» 5

После Курской битвы всем внимательным наблюдателям уже было ясно, что именно героика будет определять практики коммеморации о войне на долгие годы. На имя Сталина стала поступать масса инициативных писем, направленных на героизацию войны и памяти о ней. Вот лишь одна из типичных инициатив такого рода. 2 апреля 1944 г. к Сталину обратилась группа советских ученых и деятелей искусств во главе с академиком А.Н. Бахом, композитором Д.Д. Шостаковичем, писательницей Л.Н. Сейфуллиной и скульптором В.И. Мухиной с проектом создания монументального памятника Отечественной войны Пантеона Славы, приуроченного к 10-летию победы над фашизмом. Здесь важна не столько сама идея, сколько героический дискурс обращения: его авторы писали о «героическом эпосе Отечественной войны», «доблести героев», «подвигах богатырей оружия и труда», «героических образах и делах», «изображениях и голосах героев фронта и тыла» ${ }^{6}$. Такой ракурс трактовки войны оказался крайне живуч, в течение десятилетий он приводил не только к прославлению совершенных подвигов, но и к известной лакировке военной повседневности, затмевая собой негосударственную, непобедную сторону войны, горести и страдания народа, а также огромную цену Победы.

Героический дискурс продолжает доминировать в общественной памяти, и любые попытки исследовать тему советского героизма времен войны непредвзято зачастую воспринимаются в штыки как «дегероизация» и «девальвация подвига». Возможно, определенным компромиссным выходом из такой ситуации стал бы подход, позволяющий посмотреть на военный героизм «снизу», глазами самих фронтовиков, тем более, что за последние два десятилетия опубликовано множество их воспоминаний и интервью. Возможно, именно этот вариант на сегодняшний день является оптимальным. Предпринятый в настоящей статье анализ военного героизма основан на интервью фронтовиков-танкистов, опубликованных Артемом Драбкиным в серии «Я дрался...» и получивших широкую известность ${ }^{7}$

\footnotetext{
${ }^{1}$ Вестник Архива Президента Российской Федерации: Война: 1941-1945. М., 2010. С. 158.

${ }^{2}$ Советская пропаганда в годы Великой Отечественной войны: «коммуникация убеждения» и мобилизационные механизмы. М., 2007. С. 367-368.

${ }^{3}$ Вестник Архива... С. 154.

${ }^{4}$ Ахманаев П.В. Советская наградная система. М., 2014.

${ }^{5}$ Российский государственный архив социально-политической истории (РГАСПИ). Ф. 644. Оп. 2. Л. 34-36.

${ }^{6}$ Вестник Архива... С. 338-339.

${ }^{7}$ Драбкин А.В. Я дрался на Т-34. Обе книги одним томом. М., 2014.
} 
Выбор пал на воспоминания танкистов далеко не случайно, ведь именно танкисты, наряду с летчиками, были представителями наиболее героических воинских специальностей. Кроме того, использовался уникальный дневник Владимира Гельфанда ${ }^{8}$.

Закономерным образом возникает вопрос о достоверности использованных источников. В 1996 г. Василь Быков с горечью писал о том, что у части ветеранов сложилось специфическое отношение к войне, поскольку «они больше всех озабочены ныне, как бы спрятать правду, заменить ее пропагандистским мифологизированием, где они герои и ничего другого» ${ }^{9}$. Однако эта критика не имеет отношения к цитируемым воспоминаниям. Надо отдать должное Артему Драбкину и его команде: ветераны свободно и бесцензурно рассказывали в ходе интервью в 2001-2004 гг. не только о светлых, но и темных сторонах войны. Именно правдивость опубликованных воспоминаний сделала серию «Я дрался....» настоящим военно-историческим бестселлером.

Необходимо также отметить, что большинство наблюдений ветеранов, связанных с военной героикой, описывают главным образом ситуацию 1943-1945 гг. Этому можно дать ряд объяснений. Во-первых, большинство выживших ветеранов, принимавших непосредственное участие в боевых действиях, оказались на фронте уже во второй половине войны. Во-вторых, именно в это время образ героя-жертвы, востребованный в 1941-1942 гг., стал постепенно сменяться образами живых героев-орденоносцев, наглядно воплощавших собой грандиозные победы Красной армии и надежду на скорое окончание войны. В-третьих, именно в эти годы началось широкое награждение солдат и командиров Красной армии, что косвенно подтверждается указом Президиума Верховного Совета СССР от 2 мая 1943 г. «Об ответственности за незаконное награждение орденами и медалями СССР», призванным свести к минимуму злоупотребления властью в обстановке массового вручения наград.

Война как героизм vs война как работа. Война быстро выбивала книжные представления о героизме. Герой Советского Союза танкист Василий Брюхов с горечью вспоминал о том, как в 1943 г. на Центральном фронте в ходе наступления на Орел «сходил в разведку боем, после которой, собственно, и перестал играть в войну». После обращения командира бригады «Желающие пойти в разведку боем, шаг вперед», Брюхов вызвался добровольно. «И тут в первый и последний раз в жизни я каким-то шестым чувством, спиной, ощутил полный ненависти взгляд экипажа. Внутри все сжалось, но обратного пути уже не было», рассказывал Брюхов. В ходе разведки боем два танка из трех сгорели, был подбит также танк Брюхова, из всего взвода в живых остались сам Брюхов и заряжающий. После этого боя Брюхов прекратил «геройствовать» и стал воевать «по-настоящему» ${ }^{10}$.

Брюхову в его трактовке заглавной роли профессионализма на войне вторил Иван Маслов, кавалер ордена Александра Невского, начавший воевать еще с похода в Польшу в 1939 г.: «Я был на войне профессионалом [...]. Я на станции Барут [в пригороде Берлина] с двумя танками роты уничтожил почти десяток немецких танков, прямо на платформах. Так что мне после этого звезды надо было на корму танка наносить... Ствола бы уже не хватило, хоть он у Т-34 довольно длинный. Никогда не ждал ни от кого наград, похвал, подачек, восторженных отзывов, благодарностей, никогда не был “любимцем штаба” или “пай-мальчиком”. А просто воевал, делал свою работу по высшему разряду»"

Также быстро на фронте приходило понимание того, что главной наградой была собственная жизнь и жизнь боевых товарищей, а не орден. Танкист Георгий Кривов вспоминал о том, как в октябре 1943 г. командир 4-го гвардейского казачьего кавалерийского корпуса генерал Н.Я. Кириченко заверил, что все танкисты будут награждены «по заслугам», однако Кривов обещанной награды так и не дождался. Только в конце войны за участие в боях под Кенигсбергом и на Земландском полуострове он был награжден орденом Отечественной войны и орденом Красной Звезды. «Так что все в норме, - считал

\footnotetext{
${ }^{8}$ Гельфанд В. Дневник. 1941-1946. М., 2016.

${ }^{9}$ Цит. по: Никулин Н.Н. Воспоминания о войне. СПб., 2008. С. 236.

${ }^{10}$ Драбкин А.В. Я дрался на Т-34... С. 184-186.

${ }^{11}$ Там же. С. 436.
} 
Г.Н. Кривов, - Приятно, конечно, когда у тебя больше, но в то же время я уцелел, а многие погибли...»" ${ }^{12}$.

Продолжая тему того, что награды доставались выжившим крайне дорогой ценой, в т.ч. за счет погибших товарищей, танкист Григорий Шишкин говорил: «Все эти награды, медали, они же, по сути дела, каждому индивидууму не принадлежат. У меня есть 4 ордена. Что значит орден? В наступление идет батальон. Первый танк повернул где-то, его расстреляли. Я вижу, откуда стреляли, подавил эту пушку, продвинулся дальше. Но он-то погиб, а я остался жив. После боя награждают, а если бы его не было, может, меня подбили бы. Так что сказать, что награда принадлежит одному, ни в коем случае нельзя» ${ }^{13}$.

О цене наград так размышлял кавалер ордена Боевого Красного Знамени, ордена Отечественной войны I степени, двух орденов Отечественной войны II степени, двух орденов Красной Звезды, ордена Богдана Хмельницкого III степени, чешского ордена «Военный крест 1939 года» танкист Александр Шлемотов: «Но, знаете, лучше бы той войны не было, чем иметь все эти награды. Конечно, я ими горжусь, но очень дорогой ценой они достались» ${ }^{14}$.

Ордена как стимул к выполнению боевой задачи. Практически все ветераны были согласны в том, что награды являлись мощнейшим моральным стимулом к выполнению боевой задачи. Командир танка Иван Никонов вспоминал, как перед штурмом Будапешта в январе 1945 г. перед строем вышел полковник Ф.А. Затылкин, командир 1438-го самоходноартиллерийского полка, и расстегнул бушлат, под которым скрывался целый «иконостас» наград: «Танкисты! Вот как воевать надо! По местам!» ${ }^{15}$.

Распространенной была практика, когда командование объявляло о награждении высокими орденами, чаще всего о присвоении звания Героя Советского Союза, первым подразделениям, выполнившим поставленную командованием задачу, такую как форсирование водной преграды, захват плацдарма, штурм города. Командир танка Т-34 Герой Советского Союза Александр Фадин вспоминал о том, как перед штурмом Киева в ноябре 1943 г. командование танковой бригады объявило, что первым экипажам, ворвавшимся в город, будет присвоено звание Героя Советского Союза. Действительно, за бои за Киев Фадин, в числе семи командиров танкового батальона, был представлен к званию Героя Советского Союза, но получил это звание только в 1992 г. «За Киев» его наградили орденом Красного Знамени ${ }^{16}$. Здесь «сработала» распространенная практика, когда командование части представляло к одной награде, а вышестоящее командование выносило свой вердикт, нередко с «понижением».

Из воспоминаний танкистов следует, что в 1944-1945 гг. в танковых войсках была распространена практика награждать после операции всех выживших. Начальник штаба танкового батальона Константин Шипов рассказывал об этом так: «[...] закончилась Белорусская операция. [...] Вышли из операции - всех живых наградить обязательно. Я старался, чтобы командир роты написал наградные, но это же литература - не всем дано» ${ }^{17}$.

Особенно были важны первые награды для новичков, они играли колоссальную роль в адаптации молодого пополнения к военным условиям, свидетельствовали об их признании боевыми товарищами, всеяли уверенность в своих силах, давали надежду дожить до Победы. Герой Советского Союза Павел Кулешов вспоминал, как после освобождения Брянска его часть стала гвардейской, всем военнослужащим вручили гвардейские значки. «Много ребят было награждено орденами и медалями. Я за эту операцию награжден не был, но для меня был дорог гвардейский значок», - рассказывал Кулешов ${ }^{18}$. Молодежь нередко радовалась первым наградам как дети. Григорий Шишкин, командир Т-34, был 1 сентября 1943 г.

\footnotetext{
${ }^{12}$ Драбкин А.В. Я дрался на Т-34... С. 227.

13 Там же. С. 324-325.

${ }^{14}$ Там же. С. 360.

${ }^{15}$ Там же. С. 473.

${ }^{16}$ Там же. С. 123.

${ }^{17}$ Там же. С. 520.

${ }^{18}$ Там же. С. 283-284.
} 
награжден перед строем бригады орденом Красной Звезды. Эмоции были настолько сильны, что вспомнились спустя 60 лет: «Это для пацана тогда... я же помню по школе, когда орденоносец приходил - это было событием! А тут и мне орден дали! Ну, вообще! Конечно, детство еще было» ${ }^{19}$.

Моральный эффект орденов усиливался в сочетании с материальными стимулами, а именно выплатами за уничтоженную вражескую технику. Такая практика была введена приказом наркома обороны № 0387 «О поощрении бойцов и командиров за боевую работу по уничтожению танков противника» от 24 июня 1943 г. ${ }^{20}$ В соответствии с приказом, за каждый подбитый или подожженный танк противника командиру, механику-водителю и командиру орудия нашего танка вручалась премия в размере 500 рублей, остальным членам экипажа - по 200 рублей. Танкисты вспоминали разные истории о «наградных» деньгах, но в основном это были приятные воспоминания, связанные с поддержкой семьи или возможностью почувствовать себя на фронте «гражданским» человеком, что-то купив себе на деньги помимо пайка и казенного вещевого довольствования. Николай Железнов, командир взвода танков Т-34, сжег немецкий Т-4 на Сандомирском плацдарме в 1944 г.: «За это меня наградили орденом Красной Звезды и еще дали премию пятьсот рублей. [...] Но вообще, после операции, награждаются все уцелевшие» ${ }^{21}$. Иван Никонов рассказывал в интервью: «Утром к танку подбегает начфин батальона: “Никонов, куда перевести деньги за подбитые фашистские танки?” А нам за каждый подбитый танк давали 500 рублей. “Матери в Липецкую область”. За этот бой я был представлен к ордену Красного Знамени» ${ }^{22}$. Ему вторил Павел Кулешов: «Кстати, за подбитые танки платили деньги. Да только кто их получал? Все в Фонд обороны! Я открыл матери счет, и 1000 рублей каждый месяц ей посылали: у нее была доверенность, по ней она получала» ${ }^{23}$. Кроме того, семьи орденоносцев получали ряд льгот в соответствии с Общим положением об орденах Союза ССР и указами Президиума Верховного Совета СССР.

Командир танка T-34-85 Александр Бурцев, кавалер орденов Отечественной войны I степени и Красной Звезды, с неподдельной теплотой рассказал курьезную историю о том, как его отец распорядился его военными деньгами, в т.ч. и «наградными»: «Приехал домой, на книжке у меня было десять тысяч рублей. Отцу говорю: “Пойдем, я деньги получу”. Я отдал эти деньги, пошел домой, а отца до полуночи не было. Пришел. Деньги все целы, а сам поддатый» ${ }^{24}$.

Орденоносцы как элитарная группа. Практически все ветераны заявляли о том, что орденоносцы являлись на фронте элитарной группой. Механик-водитель Михаил Шистер вспоминал, какое впечатление произвели ветераны на молодое пополнение: «мы, “зеленые” новички, с огромным уважением смотрели на этих ветеранов бригады, на многочисленные ордена и медали на их гимнастерках, и верили, что, может, и нас, вот как их, судьба сохранит в грядущих боях» ${ }^{25}$.

Учитывая в т.ч. такой эффект, командование частей нередко целенаправленно берегло орденоносцев, в случае с танкистами - орденоносные экипажи. В результате у орденоносцев появлялась дополнительная возможность выжить, в первую очередь за счет откомандирования на учебу. Александр Фадин летом 1944 г. был награжден «редким» орденом Александра Невского и сразу же получил направление на учебу в Ленинградскую высшую бронетанковую школу ${ }^{26}$. Особенно старались сберечь Героев Советского Союза, которые зачастую воспринимались как живой «экспонат» в «музее» части. Однако суровые военные будни диктовали свои правила. Танкист Иван Маслов на вопрос, пытались ли в его бригаде

\footnotetext{
${ }^{19}$ Драбкин А.В. Я дрался на Т-34... С. 309.

${ }^{20}$ Там же. С. 599.

${ }^{21}$ Там же. С. 277.

22 Там же. С. 479.

${ }^{23}$ Там же. С. 298.

${ }^{24}$ Там же. С. 170.

${ }^{25}$ Там же. С. 454.

${ }^{26}$ Там же. С. 151.
} 
каким-нибудь образом сохранять в живых ветеранов бригады, ответил так: «И да, и нет... Опытные люди очень нужны в бою». Тем не менее Маслов тут же рассказал, что в одном из батальонов бригады был экипаж Куперштейна-Грабского, полностью составленный из Героев Советского Союза, получивших это звание еще за Киев осенью 1943 г., который без потерь довоевал до Победы. Кроме того, в бригаде был Герой Советского Союза, механик-водитель Мацак. Чтобы дать ему хоть какую-то возможность выжить, командование перевело его водителем на ремонтную «летучку» ${ }^{27}$.

Дефициты наградной системы. Наряду с сильными сторонами, советская военная наградная система демонстрировала ряд недостатков. Одним из них было гендерное неравенство в вопросах награждения. В 1943 г. женщины составляли около 8 \% от общей численности советских вооруженных сил. По мнению многих современников, женщины на фронте были не столько солдатами, сколько «полевыми походными женами», которые, в отличие от женщин в тылу, остававшихся верными своим мужьям, не испытывали проблем ни со снабжением, ни с женским одиночеством. В свете такого отношения к женщинам на фронте медаль «За боевые заслуги» нередко уничижительно именовалась медалью «За половые услуги», поскольку ею часто награждали именно женщин ${ }^{28}$.

То, что проблема гендерного неравенства в области награждений действительно существовала, из опрошенных танкистов подтвердил Василий Брюхов: «Ведь девчонки мучились-то как?! Им же труднее было в сотню раз, чем нам, мужикам! Особенно обидно за девчонок-медсестер. Они же на танках ездили, с поля боя раненых вывозили и, как правило, получали медаль “За боевые заслуги”, - одну, вторую, третью. Смеялись, что получили “За половые потуги”. Из девчонок редко кто орден Красной Звезды имел. [...] А после войны как к ним относились?! [...] Многих хороших девчонок ославили» ${ }^{29}$.

Впрочем, иногда ситуация с гендерным неравенством в вопросах наград выглядела совершенно иначе, когда женщины, близкие к командованию, получали боевые награды в нарушение всех правил и статутов. Наиболее громким примером является награждение в 1945 г. орденом Отечественной войны I степени певицы Л.А. Руслановой. Как известно, 21 июня 1947 г. Политбюро ЦК ВКП(б) приняло постановление «О незаконном награждении тт. Жуковым и Телегиным артистки Руслановой и других орденами и медалями Советского Союза», в соответствии с которым Русланова и еще 27 артистов были лишены боевых орденов и медалей.

Неоднократно к теме незаслуженного награждения женщин обращался в своих дневниках сержант, затем лейтенант Владимир Гельфанд. Эти дневники уникальны не только, как отмечает составитель, по хронологии, географии, объему и откровенности. Для изучения темы советского героизма они являются единственным в своем роде источником еще и потому, что их автор, воевавший с лета 1942 г. сначала рядовым минометчиком, потом командиром взвода и закончивший войну в Германии, очень остро реагировал на несправедливости в области вручения наград. Описывая своих сослуживиц по запасному полку в Берлине в 1945 г., Гельфанд с горечью писал: «У всех были ордена: у некоторых по несколько, в числе которых очень высокие. За что они их получили: военные люди, не задумываясь, определят цену их героизма, ибо только редкие исключения наблюдались в среде женского воинского персонала, поистине заслуживавшие уважения и внимания» ${ }^{30}$.

Еще одной острой проблемой, с точки зрения танкистов-евреев, был антисемитизм, получивший распространение в среде советского командования, когда неприязненное отношение к евреям приводило также к их ущемлению в вопросах награждения. Иона Деген, будущий известный врач и писатель, а в годы войны - младший лейтенант и командир танкового

\footnotetext{
${ }^{27}$ Драбкин А.В. Я дрался на Т-34... С. 423.

${ }^{28}$ Физелер Б. От винтовки к колыбели: советская политика в сфере семьи и гендера в контексте Великой Отечественной войны // Общество в Германии и Советском Союзе в первое послевоенное десятилетие. Травмы и надежды. Берлин; Бостон, 2020. С. 81-95.

${ }^{29}$ Драбкин А.В. Я дрался на Т-34... С. 208.

${ }^{30}$ Гельфанд В. Дневник... С. 456.
} 
взвода, вспоминал о том, как замполит бригады Смирнов заблокировал попытку комбата представить его к званию Героя Советского Союза за взятие Вильнюса, требуя сохранить «чистоту геройских рядов от всяких там Дегенов» ${ }^{31}$.

Механик-водитель Михаил Шистер передал рассказ старшего писаря штаба бригады, присутствовавшего при обсуждении наградного представления на Шистера в 1945 г. «за три подбитых танка». Начальник штаба бригады, увидев еврейскую фамилию, якобы сказал «этот перебьется», а замполит бригады не возразил. «А вроде должен был, как замполит, сказать свое “партийное слово”, мол, в нашей стране все равны», - комментировал Шистер ${ }^{32}$.

Отмечали ветераны также неравенство в вопросе награждений между высшим командным составом и подчиненными, «фронтовиками» и «тыловиками». Своеобразную нездоровую конкуренцию в наградных делах, когда старшие командиры расценивали награждение подчиненных высокой наградой чуть ли не как личное оскорбление, наглядно демонстрирует пример Василия Брюхова. 22 декабря 1944 г. в районе Секешфехервара Брюхов лично захватил документы, раскрывавшие план немецкого контрудара в районе озера Балатон. За этот захват он был награжден «полководческим» орденом Суворова. Во время награждения командир корпуса генерал-лейтенант П.Д. Говоруненко обратился к начальнику политотдела корпуса Шелеху: «“Смотри, Шелех, - сопляк, молоко на губах не обсохло, а он уже орден Суворова получил! Я еще такого ордена не имею, а он его получает!” Вместо того чтобы похвалить, порадоваться, он это произнес с таким сожалением и упреком» ${ }^{33}$. Константин Шипов в 1945 г. за бои за город Альтдам был представлен к ордену Красного Знамени. Шипов полагал, что его комбат был далеко не в восторге от того, что Шипова представили к ордену, которого он сам еще пока не получал ${ }^{34}$.

Неприязнь между «фронтовиками» и «штабными» проявлялась даже в лексике: неправедно полученная награда нередко презрительно называлась фронтовиками «орденком». Иван Маслов так вспоминал о своем конфликте с замполитом: «Появляется во время затишья: “Маслов, мы хотим тебя к ордену представить”. - “Не за ордена воюю”. - “Ну так сиди без награды”. - “Вы, товарищ комиссар, главное, себе не забудьте очередной орденок на грудь прицепить”. [...] Он получил свой орден, а мне дали, как бы в насмешку, медаль “За боевые заслуги”. Напрашивается вопрос - кто из нас двоих ходил в атаки и горел в танке, а кто в теплой штабной хате лозунги выкрикивал?» ${ }^{35}$. Приказом по 141 Отдельному танковому полку от 9 января 1943 г. Маслов действительно был награжден медалью «За боевые заслуги» за разведку боем 7 января 1943 г.

Ветераны рассказывали также о применении на фронте такой пресловутой советской наградной практики, как «разнарядка». Танкист Арсентий Родькин вспоминал о том, как их бригада осенью 1944 г. попала в окружение в боях за Двинск, и после выхода из окружения «пришла разнарядка представить троих [к званию Героя Советского Союза]. Двоих нашли, кое-чего приписали, а третьего не смогли» ${ }^{36}$.

Уже упоминавшийся выше Владимир Гельфанд с горечью писал в 1945 г.: «...война кончилась, и я остался в чем пришел на битву, хотя многие (и большинство!) тыловики или негодяи-трусы имеют полную грудь орденов. Награды вручаются за подхалимство, выслуживание, лицемерие. [...] Ордена и медали отпускались по договорам, по заказам. Надо было только заслужить расположение этих мелких, пустых людишек. Хорошему сапожнику или понравившемуся портному, кладовщику или хозработнику было легче завоевать высшую награду, нежели мужественному, честному воину [...]» ${ }^{37}$. Впрочем, в январе 1945 г. Гельфанд в худших традициях двоемыслия так писал в дневнике после встречи с сослуживцем: «Три ордена украшают его грудь. Он ходит гоголем и говорит всем, что

\footnotetext{
${ }^{31}$ Драбкин А.В. Я дрался на Т-34... С. 394.

32 Там же. С. 466.

33 Там же. С. 203.

${ }^{34}$ Там же. С. 537.

35 Там же. С. 442.

${ }^{36}$ Там же. С. 247.

${ }^{37}$ Гельфанд В. Дневник... С. 446, 456.
} 
воевал бесстрашно. Отрицать нельзя. Отрицать правительственные награды - значит отрицать справедливость. Люди со стороны не знают всей истины, и пусть их, глупцов! Обидно только за себя, и эта неотвязная мысль пытает душу» ${ }^{38}$.

Заключение. Анализ воспоминаний ветеранов Великой Отечественной войны, предпринятый в настоящей статье, дает все основания сделать вывод о высокой эффективности героического концепта и государственной политики, направленной на героизацию советского социума, в первую очередь - солдат и командиров Красной армии. Боевые ордена и медали являлись мощным моральным стимулом к выполнению сложных боевых задач, играли колоссальную роль в адаптации молодого пополнения к военным условиям, свидетельствовали о его признании боевыми товарищами, вселяли уверенность в своих силах, высоко поднимали авторитет награжденных как командиров. Превращение орденоносцев в элитарную группу диктовало максимально бережное отношение к ним со стороны командования частей, что увеличивало их шансы дожить до Победы. Давая такую высокую оценку героическому концепту, не следует забывать, что механизмы функционирования наградной системы не всегда адекватно вознаграждали жертвенный героизм советских людей, особенно рядовых бойцов, женщин-военнослужащих и младшего командного состава, далеких от высшего командования и связанных с ним привилегий.

\section{Лumepamypa}

Ахманаев П.В. Советская наградная система. М.: Фонд «Русские витязи». 2014. 560 с.

Вестник Архива Президента Российской Федерации: Война: 1941-1945 / под ред. С. Кудряшова. М., 2010. 512 с.

Гельфанд В. Дневник 1941-1946 / отв. ред. и авт. вступ. ст. О.В. Будницкий. М.: Политическая энциклопедия; Книжники, 2016. 751 с.

Драбкин А.В. Я дрался на Т-34. Обе книги одним томом. М.: Яуза; Эксмо, 2014. 608 с.

Никулин Н.Н. Воспоминания о войне. СПб.: Изд-во Гос. Эрмитажа, 2008. 244 с.

Советская пропаганда в годы Великой Отечественной войны: «коммуникация убеждения» и мобилизационные механизмы / авт.-сост.: А.Я. Лившин, И.Б. Орлов. М.: РОССПЭН, 2007. 806 с.

Физелер Б. От винтовки к колыбели: советская политика в сфере семьи и гендера в контексте Великой Отечественной войны // Общество в Германии и Советском Союзе в первое послевоенное десятилетие. Травмы и надежды / под ред. А. Чубарьяна и А. Виршинга по поручению Совместной комиссии по изучению новейшей истории российско-германских отношений. Берлин; Бостон, 2020. С. 81-95.

\section{References}

Akhmanaev, P.V. (2014). Sovetskaya nagradnaya sistema [Soviet award system]. Moscow, Fond "Russkie vityazi”. 560 p.

Drabkin, A.V. (2014). Ja dralsya na T-34. Obe knigi odnim tomom [I fought in a T-34. Both books in one volume]. Moscow, Yauza; Eksmo. 608 p.

Fizeler, B. (2020). Ot vintovki k kolybeli: sovetskaya politika v sfere sem'i i gendera v kontekste Velikoy Otechestvennoy voyny [From rifle to cradle: Soviet policy in the family and gender issues in the context of the Great Patriotic War]. In Chubaryan, A., Virshing, A. (Eds.). Obshchestvo $v$ Germanii $i$ Sovetskom Soyuze $v$ pervoe poslevoennoe desyatiletie. Travmy $i$ nadezhdy. Berlin, Boston, pp. 81-95.

Gelfand, V. (2016). Dnevnik 1941-1946 [Diary 1941-1946]. Budnitskiy, O.V. (Ed.). Moscow, Politicheskaya entsiklopediya; Knizhniki. 751 p.

Kudryashov, S. (Ed.). (2010). Vestnik Arkhiva Prezidenta Rossiyskoy Federatsii: Voyna: 19411945 [Bulletin of the Archiveof the President of the Russian Federation: The War 1941-1945]. Moscow. 512 p.

\footnotetext{
${ }^{38}$ Гельфанд В. Дневник... С. 446, 456.
} 
Livshin, A.Ja., Orlov, I.B. (Eds.). (2007). Sovetskaya propaganda v gody Velikoy Otechestvennoy voyny: "kommunikatsiya ubezhdeniya” i mobilizatsionnye mekhanizmy [Soviet propaganda during the Great Patriotic War: “communication of persuasion” and mobilization mechanisms]. Moscow, ROSSPEN. 806 p.

Nikulin, N.N. (2008). Vospominaniya o voyne [Memories of the War]. St. Petersburg, Izd-vo Gos. Ermitazha. 244 p.

Статья поступила в редакцию 12.05.2021 г. 